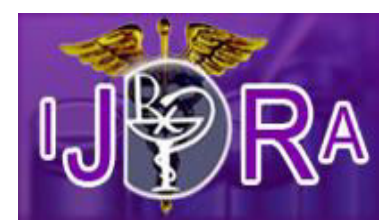

\title{
Regulation of Blood and Blood products in India, USA and EU
}

\section{Swati Gupta* and Harvinder Popli}

Delhi Pharmaceutical Sciences \& Research University (DPSRU), Mehrauli-Badarpur Road, Puspvihar Sector 3 New Delhi 110017, India.

\begin{abstract}
Blood and blood products are precious commodity which gives life to another person. Though we have immense discoveries and invention in science and technology, yet we cannot make blood hence, human blood has no substitute. The availability of safe blood and blood products is essential for diverse modern healthcare services including some surgeries, treatments for cancer, chronic medical conditions, trauma care, organ transplantation, and childbirths that ultimately improve life for millions of patients who are need of transfusion annually. We do not have yet well-defined and stringent regulatory framework for blood products regulation. Frailty may arise from the inability of governments to enforce laws, regulations, and policies and personnel who may not aware or cannot follow quality assurance and/ or good manufacturing practices. While the health sector in developed nation has made outstanding accomplishments in the past few decades. The study sheds on the overview of blood transfusion system in India and other developed nations. There were a mix of methodologies, including literature review (government documents), interviews with key officials in Indian Red Cross Society and analysis of data was used. Results of analysis showed that there are several areas that need to be addressed as it potentially affect the timely availability of safe blood products, which calls for strengthening the planning and monitoring of blood transfusion services.
\end{abstract}

Keywords: Transfusion medicine, blood transfusion, Transfusion transmitted infection (TTI).

Article Info: Received 19 May, 2018; Review Completed 28 May 2018; Accepted 30 May 2018

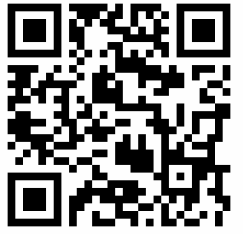

Cite this article as:

Gupta S, Popli H. Regulation of Blood and Blood products in India, USA and EU. International Journal of Drug Regulatory Affairs [Internet]. 15 Jun.2018 [cited 15 Jun. 2018]; 6(2):72-84. Available from: http://ijdra.com/index.php/journal/article/view/246

DOI: $10.22270 / i j d r a . v 6 i 2.246$

*Corresponding author. Tel.: +91-8285274412;

E-mail address: swati.dipsar@gmail.com (S.Gupta).

\section{Introduction}

With more than 1200 road accidents occurring every day in India, 60 million surgeries are performed in the country, 240 million major operations, 331 million cancers related procedures like chemotherapy and 10 million pregnancy complications all require a serious call for blood transfusion. Therefore, well-organized, well-structured and effective blood transfusion service is vital for the health-care delivery system. Unfortunately millions of people are exposed to unsafe blood due to poor storage, inappropriate checking and they might not get a blood because of the shortage, Due to scarcity of blood during an emergency, the onus is on the patient's relatives or friends to arrange for replacement of blood and here the healthcare provider fails to ensure public health.
Blood transfusion is a medical process in which blood is drawn from the healthy person transfer into patient's bloodstream (1). In India, more than 40 Lakh units of red blood cells, platelets, and plasma are transfused to treat clinical conditions and patient's serious illness (2). It is evident that Blood transfusion has been recognized as one of the eight key life-saving interventions by WHO (3).

However blood transfusions have been associated with some risk to recipient even when they have given a right blood type (4). In 1980s an incident of HIV epidemic was a great cause of fear. Nevertheless the risk has been largely eliminated by strict donor selection and improvements in testing standard of donated blood for the presence of contaminants including bacteria, viruses, and parasites (4). 


\section{Historical background of transfusion medicine}

Long before scientist really understood that blood was a magic elixir flowing inside our body. Someone who was sick or dying they would usually drink the blood which had no effect. The idea of blood transfusion didn't actually occur until William Harvey's 1628 discovery that blood circulates through the body in one direction (5).

It was then, that scholars and doctors realized that transfusion were a possible method of rejuvenating the sick. By the end of 17 th century, physicians were using quills as needles and silver pipes to transfer blood from a donor to a patient but donor was usually an animal. But no one knew at the time was animal's blood cells are incompatible with human blood. It wasn't until obstetrician James Blundell started using human blood to replace blood lost in childbirth. In the early 1800, that transfusion had started working, atleast some of the time.

Physician Karl Landsteiner set out to figure out why some blood transfusion patient lived and others died a line of inquiry that led him to discover the ABO blood type group in 1901. It was Landsteiner's groundbreaking work that helped classify blood into one of four categories: A, B, $\mathrm{AB}$ and $\mathrm{O}$. These are defined by the antigens and antibodies on the red cells $(5,6)$.

People with type A blood for example, have A antigen on the surface of their red cells and their bodies cannot produce the anti- A antibodies so, if any type A blood is introduced into that person's body, it won't recognized the new cells as foreign and won't attack them, but if type B blood is injected into a type A blood person, the anti-B antibodies on the donated blood will be seen as foreign. The host's body will reject the transfusion. A patient of a given blood group type can only be transfused with blood of the same type. Another factor for rejection comes down to protein on the surface of red blood cells called Rhesus or Rh factor. Blood cells are either possesses the protein or not. These factors combine to make eight blood types $(1,7)$.

\section{Blood usage pattern}

According to WHO blood transfusion safety report, there is a great inconsistency in the access to safe blood. (3) Many patients do not get blood when they need. It is estimated 80 million units of blood donated annually worldwide, only $38 \%$ are collected in the developing world which is home to $80 \%$ of the world's population. The shortage of blood has a significant impact on women with complications of pregnancy, children with serious life-threatening anaemia (8). Hence there is a need to have the blood donation culture to meet the annual requirements of blood to patient in developing countries. Access to a quality blood can help to prevent deaths of patients who are need of blood transfusion (9).

The requirements of blood are differs markedly across the globe. It is given in [figure 1]. These data show the importance of blood donation and usage in countries (8).

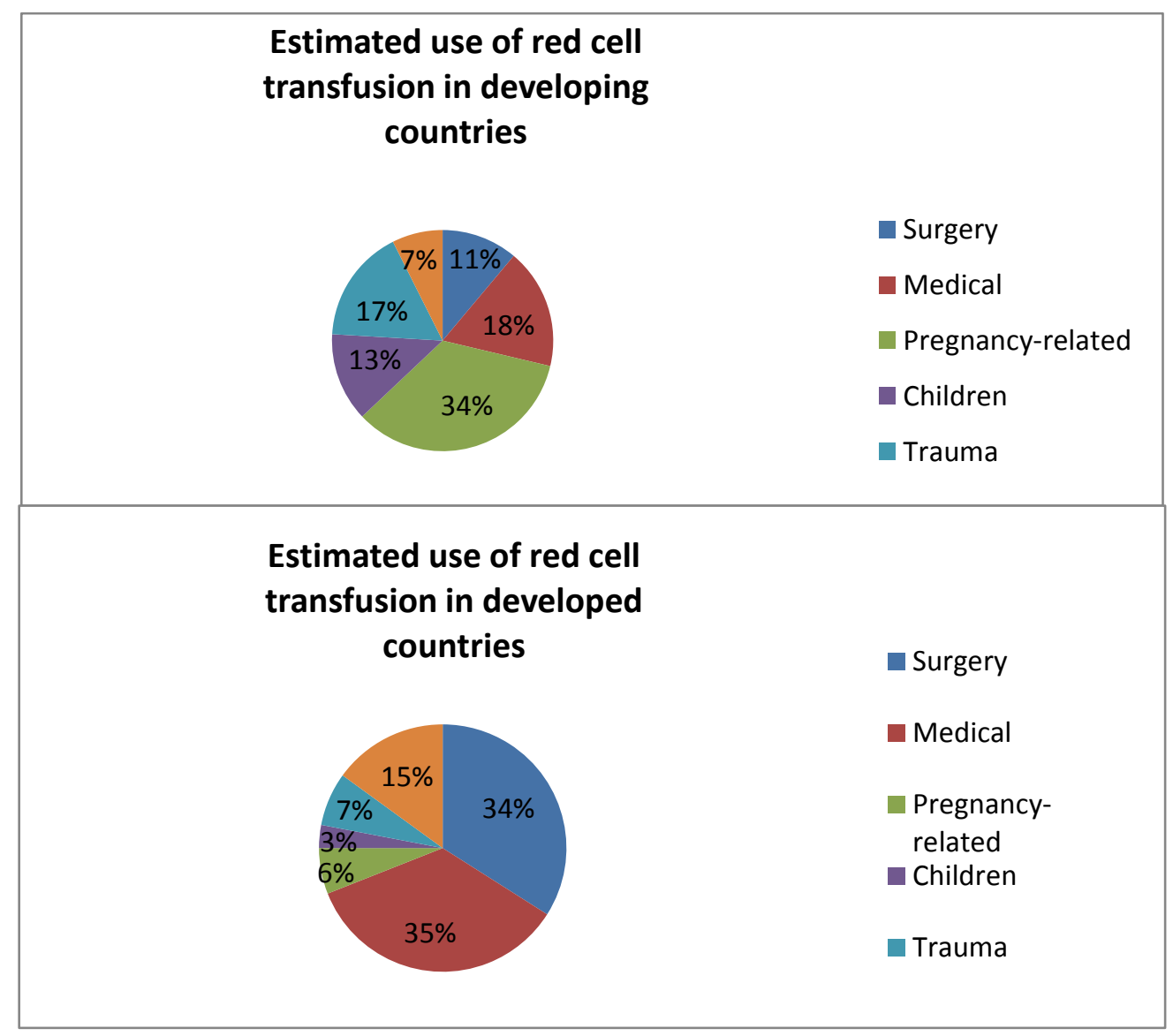

Figure 1. Blood Usage Pattern (8) 


\section{Regulation in US and $\mathrm{EU}$}

The Food and Drug Administration (FDA or USFDA) is an agency of United States department of health and human services. It is responsible for protecting and promoting public health through the regulations and supervision of drugs, food safety, tobacco products, medical devices, biologics, and cosmetics (10).

USFDA control and regulates biologics as per the following:

- Cellular \& Gene Therapy Products.

- Tissue \& Tissue Products.

- Vaccines.

- Blood \& Blood Products.

- Allergens

- Xeno transplantation.

Blood products regulation is regulated by office of blood research and review in the centre for biologics evaluation and research. Currently it has more than 150 staff that works into three divisions: the division of transfusion transmitted disease, the division of hematology, and the division of blood application (10).

While legislation/regulations in EU for blood is regulated by European Commission collaborates with Council of Europe. It is responsible for license of blood bank establishment. Legislation on blood bank is based on the good practised guideline which is described in blood directive 2005/62/EC (11).
The regulation of blood and blood products is crucial and followed continuously in every step and process that the blood passes through. These steps include: blood bank establishment, donor recruitment, donor selection, donor records maintenance, light and temperature control, storage, SOPs for performance, refrigerator usage, legal documents and records, inventory, all of which are necessary for proper blood bank maintenance and for the safety and health of the patient.

The key areas are:
$>$ Establishment of blood bank
$>$ Selection of donor
$>$ Blood Donor Education
$>$ Assessment of Fitness for Donation
$>$ Premises for Blood Donation
$>$ Testing quality
$>$ Quality assurance of blood product
$>$ Blood storage and inventory management

\section{Establishment of Blood Bank Requirement in India}

The regulatory body of India is Central Drugs Standard Control Organization (CDSCO) which is headed by the Drugs Controller General (India). The drugs controller has many more areas such as drugs, devices, biologics and clinical trial etc to look after and one of them is blood banks. The Drugs and Cosmetics Act, 1940 identify clearly about accommodation, manpower, equipment, supplies and reagents and good manufacturing practices. Licensing and monitoring of the blood bank is responsibility of Drug Controller General of India (12).

ACCORDING TO SCHEDULE F: PART XII-B

GENERAL REQUIRMENTS:

$\checkmark$ Location: an area of 100 square metre for its operations and an additional area of 50 square metres for preparation of blood components.

$\checkmark$ Surrounding: It shall be maintained in a clean and orderly manner

$\checkmark$ Building: it should have adequate space for the orderly placement of equipment and materials

$\checkmark$ Requirements for processing: blood establishment must have separate component labs for processing of blood into components and area shall not be access to other people.

$\checkmark \quad$ Storage and quarantine areas:proper racks, bins and platforms have been provided for the storage and adequate areas have been allocated for products in quarantine area.

$\checkmark \quad$ Health:Personnel must have practice good sanitation and health habit.

$\checkmark \quad$ Premises:the premises has been designed constructed and maintained to suit the manufacturing operations

$\checkmark \quad$ Cleaning and sanitation: Specify the cleaning procedure of the operation areas.

Whether cleaning procedure is validated

$\checkmark$ Waste disposal: Specify the system of disposal of biomedical waste, and effluents (solid, liquid, and gas) from the manufacturing site.

\section{KEY REQUIREMENTS:}

$>$ Collection, transportation and storage of blood products in brief.

$>$ Qualifications of medical officers, technicians and technical supervisor engaged in the work.

$>$ Quality control for testing.

$>$ Mandatory blood testing: Human Immunodeficiency Virus, Syphilis, Hepatitis B, Hepatitis C \&Malaria

$>$ List of equipments provided.

$>$ List of blood products required.

$>$ Details of labels.

$>$ Standard operating procedures 
LEGAL DOCUMENTS: Covering letter with court fee stamp with 5 rupees affixed, Form 27.C (Refer Statutory forms), Chalan for Rs. 7500 and Plan of the building.

"The licence for operating a blood bank grants in form 28 C"

\section{Processing and Approval}

For grant and renewal of licence for operation of blood bank shall be granted in Form 28-F The inspectors shall examine all the section of premises, equipment, testing facilities and other things related to operation of blood bank and processing of whole blood into components (13).



PROCESSING AND

APPROVAL BY

LICENSING

AUTHORITIES LEVEL III
1. Raise query (if inspection report is unsatisfactory, clarification from inspecting authority might be sought)

2. APPROVE APPLICATION (based upon compliance found in the inspection report)

3. REJECT APPLICATION (with valid reason given to the applicant)

\section{TIMELINE FOR APPROVAL}

120 days from the date of submission of application form, provided that documents are valid and complete as per

the checklist

Figure 2. Approval process of blood bank establishment (14) 


\section{Donor selection regulation}

Donor selection is the process which determines the eligibility of donor to donate blood on any given day. Guidelines for the selection of donors have been published by regulatory authority or many scientific organizations towards safe blood transfusions. Some of them are
National AIDS Control Organization (India), American society of Anaesthesiologists, American Association of Blood Banks and British Committee for Standards in Haematology.

The step for safety of blood products with references to managing risk the focus area must be on donor selection (15-17).
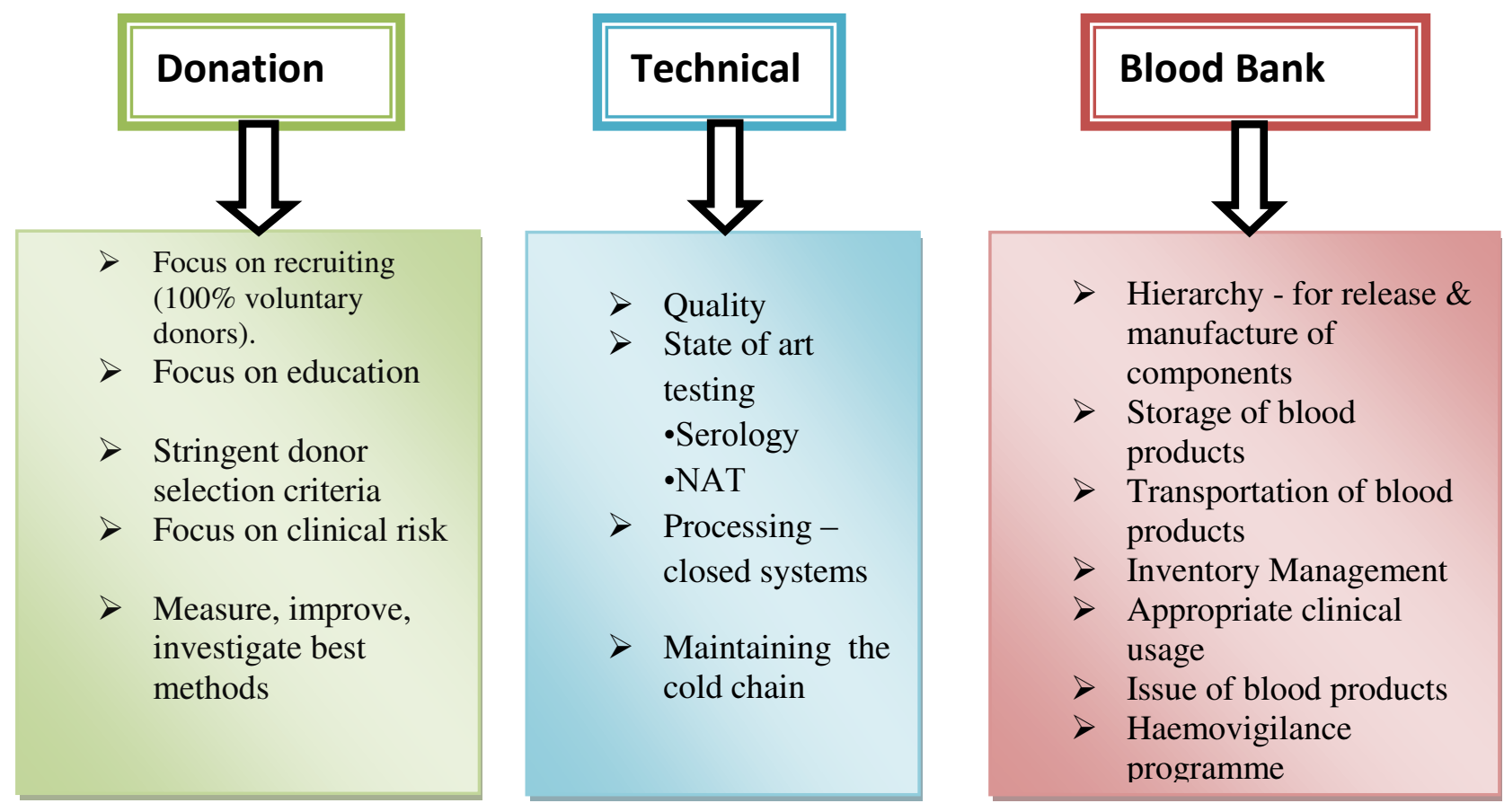

Figure 3. Regulation matrix for safe blood products (18)

\section{Regulation: safe donor selection}

- Recruit only voluntary non-remunerated regular blood donors (VNRBD) as they have the lowest frequency of transfusion transmissible infections (TTIs). Hence considered to be safest

- Procedure for safe selection of donor, appropriate interview and eligibility evaluation must be implemented as well as maintained. They must occur before each donation and must be comply with the requirements sets by each country

- There must be specific and secure identification code as well as registering of the contact details of donors.

- Upon arrival at blood bank, potential donors must provide authentication of their identity. All donors must undergo stringent screening process to assess their suitability.

- Only healthy person with good medical condition can considered as donor.
- The process of selection must include evaluation of each donor carried out by licensed physician who has been trained accepted guidelines. The evaluation tool involves a series of questionnaire about past health history, an interview and further direct questions.

- The questionnaire must be clear and information should be relevant to health condition and lifestyle of the donor. On completion of paperwork, the donor will move on to confidential interview with trained staff member in which the answer on the form will be checked. The donor is then required sign a informed consent.

- Perform safe blood collection techniques

- Donors must be instructed to inform blood bank if sign and symptoms take place after a donation

- Suitability record and final evaluation of donors must be signed by healthcare professionals of the blood bank (19).

Rigorous donor selection \& screening protocols criteria of India, US and EU is compiled in table 1.

Table 1. Donor inclusion and exclusion criteria reference (16, 20-22)

\begin{tabular}{ll}
\hline India & $\begin{array}{l}\text { outlined by CDSCO, accrediting organizations such as NABH \& nodal agency NACO } \\
\text { and individual donation centres } \\
\text { Amited states }\end{array}$ \\
American red cross society (ARCS)/AABB \\
\hline
\end{tabular}




$\begin{array}{ll}\text { European union } & \begin{array}{l}\text { Blood directive: 2004/33/EC "Eligibility of donors .....quality and safety requirements of } \\ \text { blood }\end{array}\end{array}$

\section{Donor deferral guidelines}

In the medical history interview, some conditions come up that will prevent people from being able to donate a blood, we call it "deferral". The blood centres has criteria for acceptance or deferral of blood donors. These criteria are based on international/WHO guidelines $(15,19$,).

\section{WHO Blood Donor Selection Guidelines- purpose}

\# Protection of donor's health and safety

* Ensure recipient's safety

* Ensure the highest quality of blood and blood products

* Minimise wastage of resources by collection of unsuitable donations

\section{National deferral guideline}

WHO give guidance every country must have their own blood policy. India blood collection system uses principles outlined in the Standards of Practice for Blood Transfusion (23).

Deferral criteria should consider

-donor population's profile

-Epidemiology of life threatening infections and disease

How the FDA regulates blood products



Figure 4. FDA regulation of blood products (25)

\author{
-Local culture \\ -Available resources
}

\section{Premises requirement for Blood Donation}

* Blood donation camp shall have sufficient area and the location shall be hygienic so as to allow proper operation, maintenance and cleaning.

* All information about personnel working, equipment used and facilities available at such a Camp shall be well documented and made available for inspection, if required (15).

4. Requirements in relation to Immunodiagnostic test kits and test reagents

In US, IVDs that involve blood testing kits for screening of life threatening infections is usually performed within the centre for biologics evaluation and research. Regulation of laboratories performing diagnostic kits is performed by Centre for Medicare and Medicaid services through authority Clinical Laboratory Improvement Amendment (CLIM) of 1988 (24).

\begin{abstract}
An overview of FDA approval and regulation of $\mathrm{HIV}$ screening tests

HIV screening is the first step in ensuring patient for seeking immediate treatment. Blood test kits or reagents are belongs to category of In-vitro diagnostic devices are the products that are used to collect and examine of human samples, such as blood or components or tissues, to deliver information for making health care decision.
\end{abstract}

\section{Blood donors screening IVDs devices}

Devices used for blood donor screening are regulated by the Office of Blood Research and Review (OBRR) in the Centre for Biologics Evaluation and Research (CBER). FDA regulations require that blood donor screening testing be performed and the donor screening devices used be "approved for such use" and performed "in accordance 
with the manufacturer's instructions" (21 CFR 610.40(a), (b)). FDA has enforced these regulatory requirements of IVDs that are donor screening devices including HLA testing for blood compatibility and confirmatory testing are subjected to similar regulation as that of In-vitro diagnostic devices. The regulations also require that donors of human cells, tissues, and cellular and tissuebased products (HCT/Ps) be screened for evidence of relevant communicable diseases using licensed, approved, or cleared donor screening devices (21 CFR 1271.80) (24).

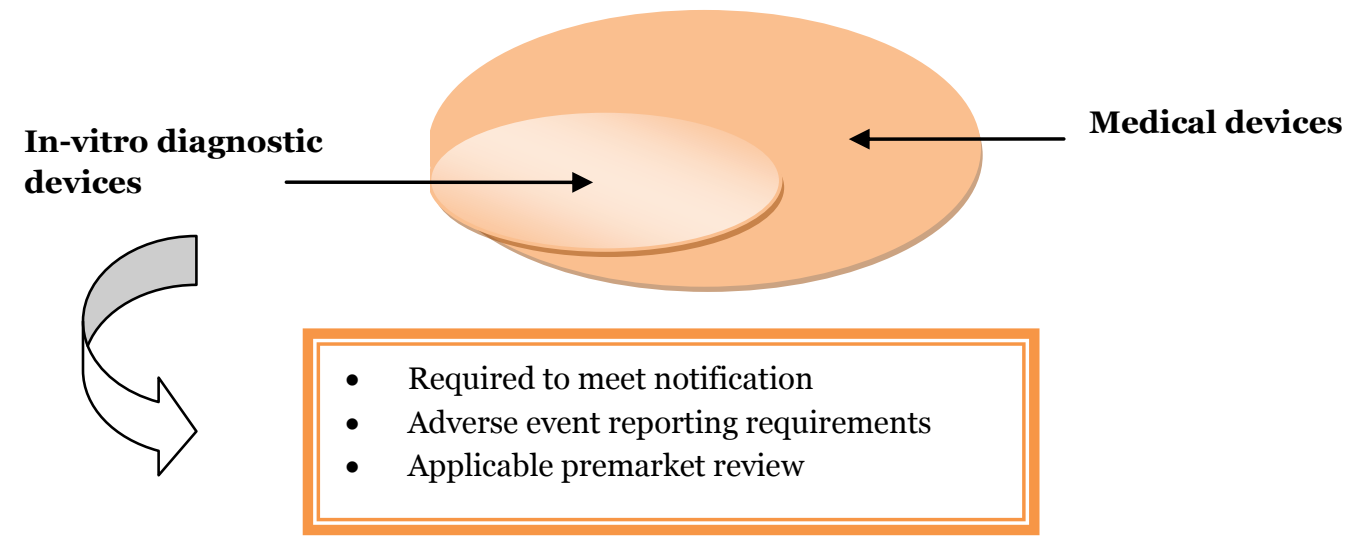

Figure 5. Share of IVDs regulation in FDA

Reporting on adverse events related to their IVDs must complete the MedWatch 3500A form available at

http://www.fda.gov/downloads/AboutFDA/ReportsManualsForms/Forms/UCM048334.pdf

MedWatch 3500A form must contain all the information described in 21 CFR Part 803.52 (26)

\section{What needs to be followed?}

For screening devices requires a most stringent regulation to ensure the safety and efficacy of blood products. Device must show "scientific evidence" that it is safe and effective in its intended use (27).

\section{Analytical validity \\ Accuracy and reliability of test to measure \\ a specific biomaker \\ Analytical sensitivity \\ $>$ Analytical specificity \\ $>$ Limits of detection \\ $>$ stability}

\section{clinical validity}

accuracy of how well a test detects or

Predicates clinical diagnoses or outcome

\section{clinical utility}

likelihood test used to inform clinical decisions and improve outcomes.
$>$ Clinical sensitivity

$>$ Clinical specificity

$>$ Prevalence

$>\quad+$ ve or - ve predictive value

Figure 6. Specific requirements to devices which is submitted for its intended use

\section{Regulation of blood screening devices in India}

The two main types of test are necessary before blood is suitable for human use, first is testing for Transfusion Transmissible Infections (TTIs) diseases and other is testing to match the blood type of the donor to the recipient. As per the drug and cosmetic act of India mandatory screening for blood donation is given in table 2.

Table 2 Mandatory screening tests/markers

\begin{tabular}{ll} 
Mandatory TTI s & Serological Markers \\
\hline Human & Antibodies to HIV-1 and 2 \\
Immunodeficiency & \\
Virus &
\end{tabular}

$\begin{array}{ll}\begin{array}{l}\text { Syphilis } \\ \text { Hepatitis B }\end{array} & \begin{array}{l}\text { Specific treponemal antibody } \\ \text { Hepatitis B surface antigen } \\ \text { (HBsAg) }\end{array} \\ \text { Hepatitis C } & \text { Anti-HCV antibody } \\ \text { Malaria } & \begin{array}{l}\text { Malaria antigen to all four } \\ \text { species plasmodium vivax, } \\ \text { falciparum, malariae and ovale }\end{array}\end{array}$

\section{Screening for Infections}

- All blood donations to be tested mandatory for five infections before it is transfused into a patient requiring blood

- For HIV Screening, it includes anti-HIV-1/2 antibodies as the minimum required screening target. 
- For viral hepatitis Screening shall contain Hepatitis B surface antigen (HBsAg) for Hepatitis B and anti$\mathrm{HCV}$ anti-body for Hepatitis $\mathrm{C}$ as the minimum required screening targets.

- Test for Syphilis shall contain specific treponemal antibodies as the minimum required screening target (28)

\section{Selection of assay/kits/reagents}

All the test kits/test regents must be licensed / CDSCO approved and mandatory to use kits before expiry date. All testing activities, handling of blood samples, sampling, analysis and data processing should be taken unconventionally diagnostic testing of patients $(28,29)$.

General principles are:

$>$ Suitable tests are performed on the correct samples.

$>$ Authentic assays are used.

$>$ Accurate and reliable results are obtained consistently.

$>$ Screened blood and blood components are available in the blood issues inventory.

$>$ Only screen non-reactive blood and blood components are released for transfusion.

$>$ Health of blood donors, recipients and staff is protected

Table 3 Classification as per Indian regulation (30)

\begin{tabular}{lll}
\hline Device name & $\begin{array}{l}\text { Risk } \\
\text { class }\end{array}$ & Intended use \\
\hline $\begin{array}{l}\text { Blood } \\
\text { Administration kits }\end{array}$ & Class B & $\begin{array}{l}\text { It is used to } \\
\text { administer blood } \\
\text { from a container to a } \\
\text { patient's vascular } \\
\text { system through a } \\
\text { needle or catheter } \\
\text { inserted into a vein }\end{array}$ \\
$\begin{array}{l}\text { In vitro Diagnostic } \\
\text { Medical Devices for }\end{array}$ & Class D & $\begin{array}{l}\text { Intended for blood } \\
\text { grouping or tissue }\end{array}$ \\
Blood Grouping or & & $\begin{array}{l}\text { typing } \\
\text { Tissue Typing }\end{array}$ \\
$\begin{array}{l}\text { Reagents/ Kits for } \\
\text { the detection of } \\
\text { transmissible agents } \\
\text { screening \& } \quad \text { Class D }\end{array}$ & $\begin{array}{l}\text { test reagents/kits is a } \\
\text { medical device } \\
\text { intended for the } \\
\text { confirmatory }\end{array}$ & $\begin{array}{l}\text { screening of life } \\
\text { threatening } \\
\text { infections }\end{array}$ \\
\hline
\end{tabular}

\section{Specific Consideration}

1. The test kits for diagnosing HIV1 and HIV 2 must be able to show the result within 30 minute after specimen/sample is applied without any calibration and calculation.

2. The test kit must be able to use directly with unprocessed specimens and unprocessed whole blood.

3. All the test kits must be presented with reagent or diluents to conduct a test without any additional manipulation.
4. After applying of specimen or reagent, the test kits should require minimal operator involvement or less procedural steps during the results

5. The test kit must be in the form that does not require any special storage conditions (e.g. refrigeration or freezers).

6. All test kit must not requires any specialized equipment such as centrifuge, washers, spectrophotometers, etc or technique to conduct or perform a test (28).

\section{Regulation in Europe}

Blood and blood products regulation is described in blood directive 2002/98/EC of European Parliament and council on setting "standards of safety and quality for the collection, processing, testing, storage and distribution of human blood and blood components "and directive 2005/62/EC which specified "community standard and specification relating to a quality system for blood establishment". Each transfusion centre must develop as well as maintain quality standard based on directive 2002/98/EC and must compliance with requirements specified in directive 2005/62/EC (31).

\section{Quality in blood establishment}

Quality system defines organizational structure, personnel's responsibilities, process controls, procedures, human resources necessary to maintain high quality services/products. In blood transfusion services quality system provide a regulatory framework for safe and effective blood transfusion to patients in needs $(31,32)$.

The components of quality system are:

- Quality management

- Blood component recall

- Quality assurance

- external and internal auditing and issuance of blood components

- Continues quality improvement, premises and personnel

- Non conformities and corrective and preventive measures are included

- Control of equipment, electronic data records and documentation

- Quality control testing of components are done following the recommended percent of all produced components

- Collection, processing and testing

- Release/issue, storage and distribution

\section{Test kits/immunodiagnostic reagents}

Screening devices use for screening of severe life threatening infection are belongs to the class D of IVDs and therefore subjected to similar regulatory requirements represented in IVD devices directive 98/79/EC which described essential requirements for products/kits and requires a manufacture to perform conformity assessment and demonstrates compliance with those of key requirements. 
Section of blood screening devices in IVD's classification

\begin{tabular}{|l|}
\hline Class D \\
High risk to public \\
Examples: \\
- HIV 1/2 \\
- Hepatitis C \& B \\
viruses \\
- Blood grooping \\
ABO \\
- Chagas \\
- syphilis \\
\hline
\end{tabular}
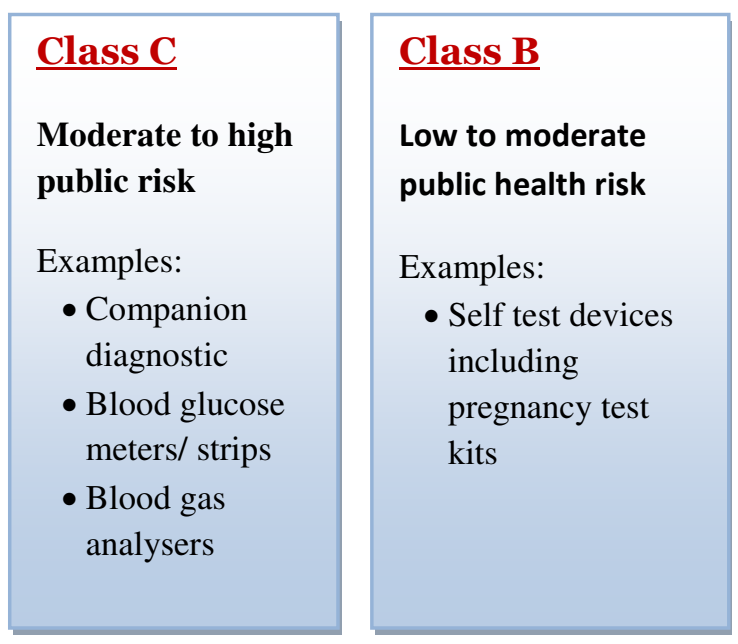

Figure 7. Classes of IVD devices (33)

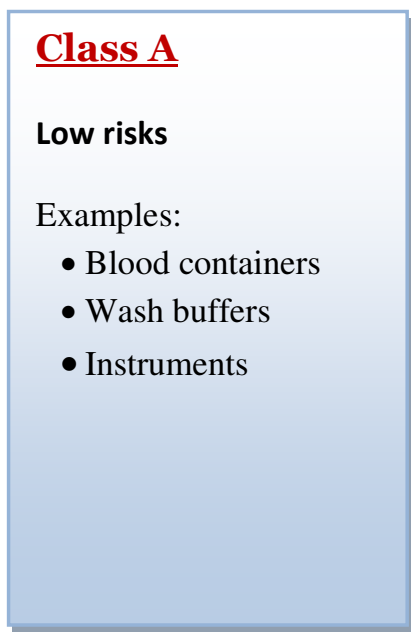

\section{Inspection of blood establishment}

Inspection is important for all blood establishment, it help to identify incident and records through critical examination of the place. Regulatory inspection is performed by competent authorities, accreditation body and EU Blood Inspection System (EUBIS) (34).

EUBIS brought by the European Commission governed by public health program to develop a standard and criteria for blood establishment inspection. Available at http://www.eubis-europe.eu.

\section{Two manuals}

$>$ EUBIS develops "criteria for inspection of blood establishments" based on directive 2002/23/EC

$>$ EUBIS audit/inspection training guidelines.

$>$ Current practices and projects by various stakeholders to improve the performance of blood transfusion

Current practices and projects by various stakeholders to improve the performance of blood transfusion

* EU-Optimal Use of Blood Project- cofounded by the European Commission main aimed is promoting improvement in the quality of transfusion practices.

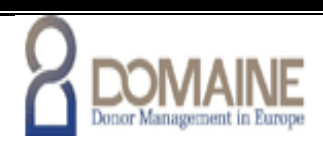

* The EU-Q-Blood -SOP Project - directed by the European Commission.

* The European Commission, Public Health Program.



* Donor management in Europe(DOMAINE)

* Engage with regulators and manufactures to promote best practices
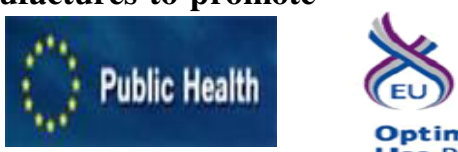

EUBIS

7. Storage, transport and distribution conditions for blood and blood components

$>$ The storage conditions play an important role in determining the effective duration for which blood and its components can be used. Typically, the blood collected after donation cannot last for more than eight hours in room conditions since it is highly prone to bacterial contamination. Due to this technological constraint, the process of component separation has to be completed within a few hours after collection. Once the components 
have been separated they have to be stored in different conditions as shown in Table 4

Table 4 Blood components stored in different conditions $(35,36)$

\begin{tabular}{lll}
\hline \multicolumn{1}{c}{ Product } & \multicolumn{1}{c}{$\begin{array}{c}\text { Storage } \\
\text { Condition }\end{array}$} & \multicolumn{1}{c}{$\begin{array}{c}\text { Max. Duration } \\
\text { of Storage }\end{array}$} \\
\hline Red Blood & $2{ }^{\circ} \mathrm{C}-6^{\circ} \mathrm{C}$ & $\begin{array}{l}35-49 \text { days } \\
\text { depending on } \\
\text { storage }\end{array}$ \\
& & $\begin{array}{l}\text { conditions } \\
\text { Platelets }\end{array}$ \\
& $20^{\circ} \mathrm{C}-24^{\circ} \mathrm{C}$ & 5 days \\
& (in a constantly & \\
stirred condition) & \\
Plasma (FFP) & $-18{ }^{\circ} \mathrm{C}$ to $-25^{\circ} \mathrm{C}$ & 1 Year \\
White Blood & No storage & - \\
Cells & possible & \\
\hline
\end{tabular}

The useful life of whole blood (WB) and RBC is considered to be 30 days which means that whole blood (WB) and RBC units which have not been transfused within one month have to be discarded. Similarly, platelets need to be discarded after five days if they have not been transfused. Since the life of platelets is very small compared to other components, blood banks typically end up discarding a lot of platelets. Plasma can survive up to almost one year in frozen state. White blood cells (WBCs) are usually not transfused. But in those cases where such transfusion is required, WBCs have to be prepared immediately since they cannot be stored (35).

\section{Refrigerator Requirements}

Refrigerators are very important in order to maintain the integrity of blood or blood components.

The blood refrigerators and plasma freezers shall be installed with the help of refrigeration expert/ maintenance technician from govt/ manufacturer's representative.
Some section must be focuses specifically on freezers or refrigerators since domestic refrigerators do not required same level of attention

1. Action on reception of refrigerators or freezers

2. Location

3. Door seals

4. Cleaning

5. Energy supply

6. Starting the equipment

\section{Temperature Monitoring}

- Standard for blood bank and transfusion services necessitate that refrigerators, freezers and platelet incubators must have a system to monitor temperature continuously and must record the temperature at least every four hours.

- Temperature shall be displayed digitally and previous recording should be readily available to easily see trends.

- On power failure, the system shall ensure no compromise of monitoring for a period of time to be specified by the manufacturer

- Data backup must ensure that in the event of hardware failure that the system integrity and temperature data integrity is not compromised.

Alarms

- In the standard for blood bank and transfusion services require that the alarms must be presented on refrigerators, freezers, and platelets incubators and must activate at temperature that will allow you to take proper action before stored blood or components reach out exceed temperature.

- An audible alarm equipped on refrigerators or freezers must be activated within seconds of temperature shifts or critical power failures, which allows you to take appropriate action before the stored units reached undesirable temperature.

- An alarm should be audible and covers maximum personnel coverage area so that immediate proper action can be taken.

- Alarm systems are mandatory to monitor a temperature as well as critical power failures and to inform unsafe temperature in order to rectify situation and move a units in timely manner. Therefore, it must be checked regularly and all checks must be recorded (35).

Table 5 Comparionsof blood products regulations and laws of India, EU and US

\begin{tabular}{|c|c|c|c|}
\hline Parameter & India & $\mathbf{E U}$ & US \\
\hline \multirow{6}{*}{$\begin{array}{l}\text { Competent authority } \\
\text { and related organisation }\end{array}$} & CDSCO headed by Drug & European Commission & (food and \\
\hline & Controller General Of & collaborates with Council & administration). \\
\hline & India: license and regulation & of Europe $(\mathrm{CoE})$ for & \\
\hline & of blood bank & $\begin{array}{l}\text { license blood bank } \\
\text { establishment. }\end{array}$ & $\begin{array}{lll}\text { Centre for biologics } \\
\text { evaluation and research }\end{array}$ \\
\hline & $\begin{array}{l}\text { National AIDS Control } \\
\text { Organization (NACO) acts }\end{array}$ & Joint Accreditation ICT & $\begin{array}{l}\text { (CBER) responsible for } \\
\text { devices related to blood and }\end{array}$ \\
\hline & as a supporter of & Europe & cellular products. \\
\hline
\end{tabular}


Ministry of Health and (JACIE).

Family Welfare to Indian blood transfusion services

Blood products safety is ensured through the, DAC (Department of AIDS Control) by providing all test kits

\section{Accreditation board}

$\mathrm{NABH}$

Laws and regulation

\section{Donor selection and interview}

\section{Serological testing} of donation
The Drugs and Cosmetics Act, 1940 identify clearly about accommodation, manpower, equipment, supplies and reagents, good manufacturing practices

Schedule F Part XII-B "requirements for functioning and operation of blood bank "
2002/98/EC "Standards of quality and safety for the collection, testing, processing, storage, \&distribution of human blood and blood components.

2004/33/EC "Eligibility of donors .....quality and safety requirements of blood

EDQM guide to the preparation use and quality assurance of blood components

European pharmacopeia $8^{\text {th }}$ edition

\section{Specified by CDSCO/ NACO/red cross society/individual hospital Eligibility criteria doesn't account for any travel history, Men who have sex with other men and exchange sex for drug and money \\ No up gradation from past 12 years}

HIV1 \&HIV 2

Hepatitis

Ebola virus

Chickungunya virus

Dengue virus

Cytomegalovirus

West nile virus

Herpes simplex virus

Malaria

Babesiosis

Syphilis

Neisseria gonorrhoea
Accreditation board:

American Association of

Blood Banks (AABB) develops and enforces a quality standard.

Food drug and cosmetic act of 1938

Centre for Medicare and Medicaid Services (CMS)

The Clinical Laboratory Improvement Amendments (CLIA) of 1988

21 CFR Code of Federal Regulations

- 606: cGMP for blood and blood components

- 610: regulatory requirement for donor screening devices.

- 803: MDR requirements

- 814: premarket approval requirements

- 820: quality system regulation requirements.

Sets by American red cross society/AABB\& FDA

- Previous residents of other countries.

- Zika virus infection

- Mad cow disease

- West nile viruses

Recently introduced

- Men who have sex with other men.

- Exchange sex for drug and money

- Medical procedure that involve receipt of dura mater graft

Blood donor screening and testing

- Chagas disease

- Haemoglobin screening/ iron management

- Hepatitis

- HIV

- Malaria

- West nile virus

- Zika virus 


\section{Post-donation follow up and hemovigilance}

- Indian Pharmacopoeia Commission (IPC), in collaboration with National Institute of Biologicals (NIB)

- National blood donor vigilance programme under the haemovigilance programme of India
European haemovigilance network (EHN)

Legal framework:

Article 9 of

Directive2005/61/EC

Viligance pyramids

- Rapid alerts

- Notification of adverse occurrences

- Surveillance of emerging risks

\section{Conclusion}

Blood transfusions are so ingrained in clinical transfusion practice for treatments of many clinical situation and haematological care. Apparently Indian blood transfusion industry is considered an area which requires legal regulations as industry not only fragmented or decentralised, but equally diversified in ownership pattern. Our analysis suggested that several areas are needs to be addressed for example donor management, improvement in quality standard of testing, regular checking and maintenance of temperatures, storage and re-evaluation of GMP for blood establishment etc. The blood supply system in EU provides a strict and highly regulated blood centres in terms of good practice guideline, quality standards, donor management, testing standards, various actives and projects for improvements and inspections of blood transfusion services. The USFDA also has its own hefty regulation for blood products that provides regulations, guidance and other measures to boost blood availability. We really must change transfusion medicine practice as there is no other alternative. This change will be from products focus to patient focus.

\section{Acknowledgments}

I take this opportunity to express deep sense of gratitude to IJDRA journal for publishing my article.

\section{Conflict of interest}

The authors declare that there are no conflicts of interest.

\section{References}

1. Blood [Internet]. Wikipedia; 2017 [cited 13 December 2017] Available from:

http://en.wikipedia.org/wiki/Blood.

2. Component utilization [Internet]. TNMGRMU Repository; 2016 [cited 2017 Dec 13]. Available from:

http://repository-tnmgrmu.ac.in/5344/1/202101116 parmatma_prasad_tripathi.pdf

3. Global Blood Safety and Availability - Key Facts and Figures 2016 [Internet]. World Health Organization; 2016 [cited 2018 Feb 23]. Available from:

http://www.who.int/mediacentre/factsheets/fs279/en/

4. Perez P, Salmi LR, Follea G, Schmit JL, et al, and the French Haemovigilance Network. Determinants of transfusion-associated bacterial contamination: results of the French BACTHEM Case-Control
Study [Internet]. Pubmed; 2001 Jul [cited 2018 Feb 24]. 41(7):862-72. Available from Medline: https://www.ncbi.nlm.nih.gov/pubmed/11452153?re port=medline $\&$ format=text.

5. History of blood transfusion. Background of transfusion [Internet]. News Medical Lifesciences; 2017 [cited 2018 Mar 2]. Available from: https://www.news-medical.net/health/History-ofBlood-Transfusion.aspx

6. Highlights of Transfusion Medicine History [Internet]. AABB; 2018 [cited 2018 Mar 2] Available from: http://www.aabb.org/tm/Pages/highlights.aspx

7. American Society of Hematology. Blood Basics [Internet]. Washington: 2018 [cited on 12 December 2017] Available from:

http://www.hematology.org/Patients/BloodBasics/5222.aspx

8. Universal access to safe blood transfusion [Internet]. WHO; 2009 [cited 2018 Feb 17]. Available from: /http://www.who.int/bloodsafety/en/Blood_Transfusi on_Safety.pdf

9. Towards $100 \%$ Voluntary Blood Donation [Internet]. WHO global framework for action; 2010 [cited 2018 Mar 4] Available from:

http://www.who.int/bloodsafety/publications/978924 1599696_eng.pdf?ua=1.

10. U.S. Food and Drug Administration. Navigate the Vaccines, Blood \& Biologics Section [Internet]. FDA; 2018 [cited 2018 Mar 5]. Available from: http://www.fda.gov/BiologicsBloodVaccines/default. htm.

11. British Committee for Standards in Haematology Guidelines [Internet]. Haematology Guidelines; 2017 [cited 2018 Jan 26]. Available from: http://www.bcshguidelines.com

12. Regulatory requirements of blood bank [Internet]. CDSCO; 2012 [cited 2018 Mar 8]. Available from: http://www.cdsco.nic.in/writereaddata/Drugs and CosmeticAct.pdf.

13. For grant/renewal of blood bank license [Internet]. CDSCO, 2012. [Cited 2018 Mar 8] Available from: http://www.cdsco.nic.in/writereaddata/BLOOD\%20 BANKS\%20INDIAfeb2015.pdf.

14. Approval process of blood bank establishment [Internet]. State drug control administration; 2017 [cited 2018 Mar 10]. Available from: http://sdc.eodbassam.in/category/online-services/

15. Blood donor selection [Internet]. WHO; 2018 [cited 2018 Mar 11]. Available from: 
http://www.who.int/bloodsafety/publications/bts_gui deline_donor_suitability/en/

16. Eligibility criteria [Internet]. American Red Cross Society; 2018 [cited 2018 Mar 15]. Available from: https://www.redcrossblood.org/donate-blood/how-todonate/eligibility-requirements/eligibility-criteriaalphabetical.html.

17. Indian blood bank [Internet]. donor guidelines; 2018 [cited 2018 Mar 16)]. Available from: http://indianbloodbank.com/donors-guidelines.html

18. Donor selection principle [Internet]. IPFA Workshop SPIER Stellenbosch; 2015 [cited 2018 Mar 5]. Available from:

https://ipfa.nl/UserFiles/File/WS\%202015/IPFA\%20 Cape\%20Town\%202015/Proceedings\%20Publicly\% 20Published/WG1_1_Ingram.pdf

19. World Health Organisation: Recruiting, Educating and Retaining [Internet]. Safe Blood Donors Geneva, Switzerland: World Health Organization; 2010 [cited 2018 Mar 10]. Available from:

http://www.who.int/hrh/migration/code/WHO_globa 1_code_of_practice_EN.pdf.

20. Donor eligibility [Internet]. AABB; 2018 [cited 2018 Mar 17]. Available from:

http://www.aabb.org/advocacy/regulatorygovernmen t/donoreligibility/Pages/default.aspx

21. Donor inclusion and exclusion criteria [Internet]. NACO; 2017. [Cited 2018 Mar 18]. Available from: http://naco.gov.in/sites/default/files/Letter\%20reg.\% 20\%20guidelines $\% 20$ for $\% 20$ blood $\% 20$ donor $\% 20$ sel ection\%20\%26\%20referral\%20-2017.pdf

22. Blood- European Commission. Requirements for donation [Internet]. EMEA; 2018 [cited 2018 Mar 20]. Available from:

https://ec.europa.eu/health/blood_tissues_organs/blo od_en

23. Donor deferral guideline. WHO Safe Blood Safe Donor Selection [Internet]. WHO; 2009. [cited 2018 Mar 15]. Available from:

http://www.who.int/bloodsafety/en/Blood_Transfusi on_Safety.pdf

24. FDA regulation for donor screening devices. Testing protocol [Internet].FDA; 2018 [cited 2018 Mar 24]. Available from:

http://www.fda.gov/MedicalDevices/DeviceRegulati onandGuidance/IVDRegulatoryAssistance/ucm1236 82.htm

25. FDA. Requirements for Blood and Blood Components Intended for Transfusion or for Further Manufacturing Use [Internet]. Federal Register; Vol. 80, No. 99; 2015 May 22 [cited 2018 Mar 25]. Available from:

https://www.federalregister.gov/documents/2015/05/ 22/2015-12228/requirements-for-blood-and-bloodcomponents-intended-for-transfusion-or-for-furthermanufacturing

26. FDA- Reporting requirements [Internet]. MEDWATCH form; 2018 [cited 2018 Mar 25]. Available from: http://www.fda.gov/downloads/AboutFDA/Reports ManualsForms/Forms/UCM048334.pdf

27. FDA- Reporting requirements [Internet]. FDA; 2018. [cited 2018 Mar 25]. Available from:
http://www.fda.gov/downloads/AboutFDA/Reports ManualsForms/Forms/UCM048334.pdf

28. National Guidelines for HIV testing [Internet]. National AIDS Control Organisation; 2015 [cited 2018 Mar 23]. Available from: http://www.naco.gov.in/sites/default/files/National_ Guidelines_for_HIV_Testing_21Apr2016.pdf.

29. Quality Control of $\mathrm{ABO}$ and $\mathrm{Rh}$ blood grouping reagents [Internet]. Guidance Manual; 2012 [cited 2018 Mar 26]. Available from:

http://nib.gov.in/guidance_document/Guidance_man ucal_QC_ABO_Rh_blood_grouping_reagents.pdf

30. Classification of devices [Internet]. CDSCO new rule; 2018 [cited 2018 Mar 28]. Available from: http://www.cdsco.nic.in/writereaddata/Classification $\% 20$ of $\% 20$ Medical\%20devices\%20and\%20_updated .pdf

31. EU Standards of quality of blood product [Internet]. Guidelines for blood establishment; 2006 [cited 2018 April 1]. Available from:

Directive 2001/83/EC:

https://ec.europa.eu/health/sites/health/files/files/eudr alex/vol1/dir_2002_98/dir_2002_98_enpdf.

32. EU Technical requirements of blood. Technical requirements for blood and blood components [Internet]. EMEA; 2004 [cited 2018 April 12]. Available from:

http://www.ema.europa.eu/docs/en_GB/document_li brary/Regulatory_and_procedural_guideline/2009/10 /WC500004484.pdf

33. European regulation of IVD [Internet]. Classification of IVD; 2012 [cited 2018 April 13]. Available from: https://www.bsigroup.com/meddev/LocalFiles/zh$\mathrm{cn} /$ Events/BSI-md-consultants-day-european-ivdregulations-and-risk-based-classificationpresentation-zh-cn.pdf

34. EU blood establishment inspection system [Internet]. Quality management; 2006 [Cited 2018 Apr 18]. Available from: http://www.eubis-europe.eu.

35. Standards for blood storage centres [Internet]. Ministry of Health and Family Welfare-NACO; 2009 [cited 2018 April 19]. Available from: http://naco.gov.in/sites/default/files/Guidelines\%20f or\%20Setting\%20up\%20Blood\%20Storage\%20Cent res.pdf

36. AABB Standards for storage and transport [Internet]. Blood Products by Temperature Group; 2016 [cited 2018 April 20]. Available from: http://williamlabs.com/support/aabb-fdaresources/aabb-temperature-guidelines-2009-storageand-transport/ 